\title{
表面一様加熱を受ける不均質円板の熱応力緩和と 遮熱性向上を考慮した材料組成多目的最適化問題*
}

\author{
河 村 隆 介*1, 谷 川 義 信*1
Multiobjective Optimization Problem of Material Composition Taking into Account Thermal Stress Relaxation and Improvement of Heat Resistance for a Nonhomogeneous Circular Plate due to Uniform Heat Supply from its Surfaces

\author{
Ryuusuke KAWAMURA and Yoshinobu TANIGAWA
}

\begin{abstract}
In this paper, one-dimensional transient heat conduction and thermal bending problems under the axisymmetic condition are developed theoretically for a nonhomogeneous circular plate due to a uniform heat supply from its surfaces. We constructed the approach for multiobjective optimization of nonhomogeneous material composition for a functionally graded circular plate, taking into account the thermal stress relaxation and improvement of the heat resistance. We have dealt with this multiobjective optimization using the weighting method. Using both these analytical solutions for the temperature field and the associated thermoelastic one, and the approach for multiobjective optimization of a nonhomogeneous material composition, numerical calculations of optimal material composition are carried out for a titanium alloy/zirconium oxide functionally graded circular plate subjected to a uniform heat supply from one side of its surface. The tradeoff relationship between the maximum absolute stress ratio and the maximum heat flux is elucidated. It is shown that this approach is useful for the multiobjective optimal design of nonhomogeneous material composition, taking into account both securement of strength against thermal stress and improvement of heat resistance against thermal loads.
\end{abstract}

Key Words: Thermoelasticity, Thermal Stress, Thermal Bending, Nonhomogeneous Materials, Circular Plate, Material Design, Material Composition, Multiobjective Optimization

\section{1. 緒言}

傾斜機能材料の宇宙航空分野への応用として, 宇宙 往還機の熱防御材やスクラムジェットェンジンの燃焼 室壁材への使用を目的とした高遮熱性をもつ熱応力緩 和形傾斜機能材料の開発が期待されている。使用環境 を想定した熱応力緩和形傾斜機能材料の材料組成の決 定に際しては，熱伈力に対寸る強度の確保とともに， 熱負行に対する遮熱性を高めることが主要な目的(1) と考えられる。しかしながら，熱心力に対する強度の 確保と熱負荷に対する遮熱性の向上という二つの目的 が同時にどの程度達成できるかについては十分検討さ れていない.

そこで，本研究は，板厚方向に関して不均質な材料 特性をもつ川板を解析対象としてとりあげ，表面から 様加熱在受ける場合を想是し，熱伈力に対する強度 の確保と熱負荷に刘する遮熱性の向上という二つの目 的を闰時に達成与るための材料組成最適化問題につい

\footnotetext{
* 源稍受付 1997 年 1」 20 H.

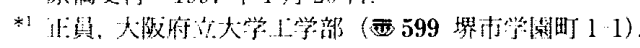

て検討したものである。まず，板厚方向に不均質な材 料特性をもつ円板が表面から一様加熱を受ける場合に ついて，一次元非定常熱伝導問題および軸対称熱曲げ 問題の理論解析を行う。次に, 熱応力に対する強度の 確保と熱負荷に対する遮熱性の向上という二うの目的 考虑した材料組成の多目的最適化手法の構築を行 う.そして，チタン合金ージルコニア系傾斜機能円板 が片側表面から一様加熱を受ける場合を想定し，本解 析結果に基づく最適化数值シミュレーションによっ て, 強度と遮熱性とのトレードオフ関係を明らかにす 3.

\section{2. 解析}

2 章では，まず不均質円板の一次元非定常熱伝導問 題に関与る著者らの多層層状体による近似解析法，打 よび不均質円板の熱曲げ問題に関する古典朋げ理論に 基づいた理論解析を示す。次に，熱応力緩和と遮熱性 向上という二.つの目的を考虑した不均質材料組成の多 四的最適化問題の取扱いについて述べる.

$2 \cdot 1$ 熱伝導解析 板厚方向に関して不均質な材 
料特性をもつ構造要素を対象とした熱伝導問題の解析 方法として，板厚方向に関して均質な多層に仮想的に 分割され，かつ各層の物性值がわずかずつ変化する多 層層状体と近似して理論解析を行う手法(2)(3) 用い る.そこで, 不均質円板の解析モデルとして，図 1 に 示すような厚さ $H$, 半径 $R$ の $N$ 層からなる多層層状 円板を想定する，各層を下面加ら順次 $i=1, \cdots, N$ と 添字をつけて区別し, $i$ 番めの層の厚さを $l_{i}$ とする. また, 各層の下面を原点とする局所座標 $z_{i}$ を設定す る.

円板の加熱条件として, 初期実温度が $\Theta_{0}$ であり, 時刻 $t=0$ の瞬間より円板の下面, 上面が一様温度 $\Theta_{a}, \Theta_{b}$ の周囲媒体により, 相対熱伝達率 $h_{a}, h_{b}$ で加 熱され，かつ側面は断熱条件の場合を想定する.

まず, 次式で定義される温度変化を導入する.

$$
\left.\begin{array}{l}
T_{a}=\Theta_{a}-\Theta_{0} \\
T_{b}=\Theta_{b}-\Theta_{0} \\
T_{i}=\Theta_{i}-\Theta_{0}
\end{array}\right\}
$$

ここで, $\Theta_{i}, T_{i}$ は各層の実温度および温度変化を意味 する。

板厚方向に関する局所座標 $z_{i}$ を用いて, 各層での 熱伝導の基礎方程式, 初期条件, 温度境界条件, 界面 での温度および熱流の連続条件を無次元表示すれば

$$
\begin{aligned}
& \frac{\partial \bar{T}_{i}}{\partial \tau}=\bar{\varkappa}_{i} \frac{\partial^{2} \bar{T}_{i}}{\partial \bar{z}_{i}^{2}}, i=1, \cdots, N \cdots \cdots \\
& \tau=0: \bar{T}_{i}=0, i=1, \cdots, N \quad \cdots \cdots \\
& \bar{z}_{1}=0: \quad-\frac{\partial \bar{T}_{1}}{\partial \bar{z}_{1}}+H_{a} \bar{T}_{1}=H_{a} \bar{T}_{a} \\
& \bar{z}_{N}=\bar{l}_{N}: \frac{\partial \bar{T}_{N}}{\partial \bar{z}_{N}}+H_{b} \bar{T}_{N}=H_{b} \bar{T}_{b}
\end{aligned}
$$

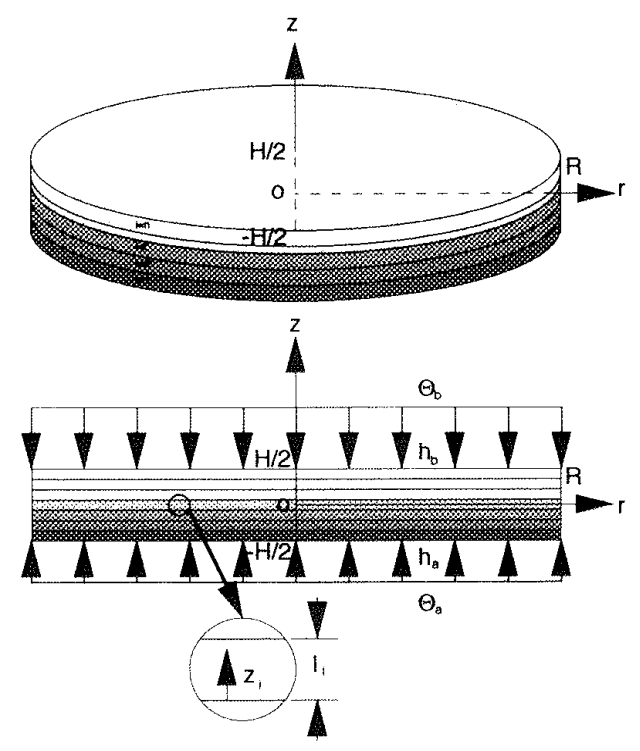

Fig. 1 Analytical model and conditions

$$
\begin{aligned}
& \bar{z}_{i}=\bar{l}_{i}, \bar{z}_{i+1}=0: \bar{T}_{i}=\bar{T}_{i+1}, i=1, \cdots, N-1 \\
& \bar{\lambda}_{i} \frac{\partial \bar{T}_{i}}{\partial \bar{z}_{i}}=\bar{\lambda}_{i+1} \frac{\partial \bar{T}_{i+1}}{\partial \bar{z}_{i+1}}, i=1, \cdots, N-1
\end{aligned}
$$

となる。

ただし，式(2)〜（7)において導入された無次元量 は次式で定義される。

$$
\left.\begin{array}{l}
\left(\bar{z}_{i}, \bar{l}_{i}\right)=\left(z_{i}, l_{i}\right) / R \\
\left(\bar{T}_{i}, \bar{T}_{a}, \bar{T}_{b}\right)=\left(T_{i}, T_{a}, T_{b}\right) / T_{0} \\
\bar{\varkappa}_{i}=\bar{\lambda}_{i} /\left(\bar{c}_{i} \bar{\rho}_{i}\right) \\
\bar{\lambda}_{i}=\lambda_{i} / \lambda_{0} \\
\bar{c}_{i}=c_{i} / c_{0} \\
\bar{\rho}_{i}=\rho_{i} / \rho_{0} \\
\tau=\lambda_{0} t /\left(c_{0} \rho_{0} R^{2}\right) \\
\left(H_{a}, H_{b}\right)=\left(h_{a}, h_{b}\right) \cdot R
\end{array}\right\}
$$

ただし， $\varkappa_{i}, \lambda_{i}, c_{i}, \rho_{i}$ はそれぞれ，各層の温度伝導率， 熱伝導率, 比熱および密度であり， $\lambda_{0}, c_{0}, \rho_{0}, T_{0}$ は基 準となる熱伝導率, 比熱, 密度および温度変化を意味 する。

式(2)を式(3)〜(7)のもとで Laplace 変換法に より解けば, 各層の無次元温度変化 $\bar{T}_{i}$ は次式で与え られる。

$$
\left.\begin{array}{rl}
\bar{T}_{i} & =A_{i}^{\prime}+B_{i}^{\prime} \bar{z}_{i} \\
& +\sum_{j=1}^{\infty} \frac{2 \exp \left(-\mu_{j}^{2} \tau\right)}{\mu_{j} \Delta^{\prime}\left(\mu_{j}\right)}\left(\bar{A}_{i} \cos \beta_{i j} \bar{z}_{i}+\bar{B}_{i} \sin \beta_{i j} \bar{z}_{i}\right) \\
\beta_{i j} & =\mu_{j} / \sqrt{\overline{\mathcal{K}}_{i}}
\end{array}\right\}
$$

上式において，係数 $A_{i}, B_{i}$ および $A_{i}^{\prime}, B_{i}^{\prime}$ は次式に示 す $2 N$ 元の連立方程式の解である.

$$
\left.\begin{array}{l}
{\left[a_{i k}\right]\left\{x_{k}\right\}=-\left\{c_{i}\right\} / \mu_{j}^{2}} \\
{\left[e_{i k}\right]\left\{x_{k}^{\prime}\right\}=\left\{c_{i}\right\}}
\end{array}\right\}
$$
ただし

$$
\left.\begin{array}{l}
\left\{x_{k}\right\}=\left\{A_{1}, B_{1}, \cdots, A_{N}, B_{N}\right\}^{T} \\
\left\{x_{k}^{\prime}\right\}=\left\{A_{1}^{\prime}, B_{1}^{\prime}, \cdots, A_{N}^{\prime}, B_{N}^{\prime}\right\}^{T}
\end{array}\right\}
$$

式(10)に切いて, 係数マトリックス $\left[a_{i k}\right],\left[e_{i k}\right]$, 定数 ベクトル $\left\{c_{i}\right\}$ のうち零でない成分は

$$
\left.\begin{array}{l}
a_{11}=H_{a} \\
a_{12}=-\beta_{1 j} \\
a_{2 i, 2 i-1}=\cos \beta_{2 j} \bar{l}_{i} \\
a_{2 i, 2 i}=\sin \beta_{i j} \bar{l}_{i} \\
a_{2 i, 2 i+1}=-1 \\
a_{2 i+1,2 i-1}=-\bar{\lambda}_{i} \beta_{i j} \sin \beta_{i j} \bar{l}_{i} \\
a_{2 i+1,2 i}=\bar{\lambda}_{i} \beta_{i j} \cos \beta_{i j} \bar{l}_{i} \\
a_{2 i+1,2 i+2}=-\bar{\lambda}_{i+1} \beta_{i+1 j}
\end{array}\right\} i=1, \cdots, N-1
$$




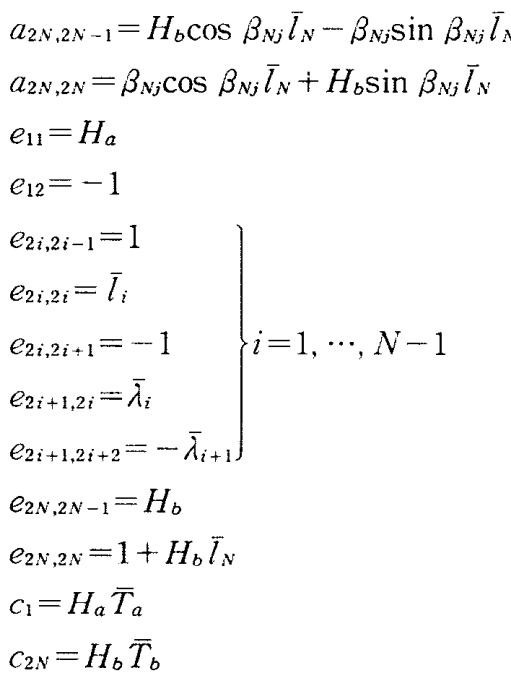

である。また，式( 9 )の $\bar{A}_{i}, \bar{B}_{i}$ は，連立方程式(10)を $A_{i}, B_{i}$ について解き，その解を次式のように表したも のである.

$$
\left.\begin{array}{l}
A_{i}=-\bar{A}_{i} /\left\{\mu_{j}^{2} \Delta\left(\mu_{j}\right)\right\} \\
B_{i}=-\bar{B}_{i} /\left\{\mu_{j}^{2} \Delta\left(\mu_{j}\right)\right\} \\
\Delta\left(\mu_{j}\right)=\operatorname{det} a_{i k}
\end{array}\right\}
$$

さらに固有值 $\mu_{j}$ は

$$
\Delta(\mu)=0
$$

を満たす $j$ 番めの正根であり, $\Delta^{\prime}\left(\mu_{j}\right)$ は次式を意味す る.

$$
\Delta^{\prime}\left(\mu_{j}\right)=\lim _{\mu \rightarrow \mu_{j}} \frac{d \Delta(\mu)}{d \mu}
$$

$2 \cdot 2$ 熱曲げ解析 $2 \cdot 1$ 節で求められた温度変化 による不均質円板の熱曲げ問題について，平板の古典 曲げ理論 ${ }^{(4)}$ に基づいて理論解析を行う。板の変形に 関する Kirchhoff-Love の仮説に基づき，加熱条件の 軸対称性を考慮する。 $u_{0}, w$ をそれぞれ，中央面の半 径方向の面内変位および面外変位とすれば，このとき， 各層のひずみ成分 $\varepsilon_{r r i}, \varepsilon_{\theta \theta i}$ は，次式のように無次元表 示される。

$$
\left.\begin{array}{l}
\bar{\varepsilon}_{r r i}=\frac{d \bar{u}_{0}}{d \bar{r}}-\bar{z} \frac{d^{2} \bar{w}}{d \bar{r}^{2}} \\
\bar{\varepsilon}_{\theta \theta i}=\frac{\bar{u}_{0}}{\bar{r}}-\bar{z} \frac{1}{\bar{r}} \frac{d \bar{w}}{d \bar{r}}
\end{array}\right\}
$$

次に各層の応力成分を $\sigma_{r r i}, \sigma_{\theta \theta i}$ とし, $E_{i}, \nu_{i}, \alpha_{i}$ を縦弾 性係数, ポアソン比および線膨張係数とすれば, 応力一 ひずみ関係式の無次元表示は次式となる。

$$
\left.\begin{array}{c}
\bar{\varepsilon}_{r r i}=\frac{\bar{\sigma}_{r r i}-\nu_{i} \bar{\sigma}_{\theta \theta i}}{\bar{E}_{i}}+\bar{\alpha}_{i} \bar{T}_{i} \\
\bar{\varepsilon}_{\theta \theta i}=\frac{\bar{\sigma}_{\theta \theta i}-\nu_{i} \bar{\sigma}_{r r i}}{\bar{E}_{i}}+\bar{\alpha}_{i} \bar{T}_{i}
\end{array}\right\}
$$

このとき, 円板の平衡方程式は次式のように無次元表 示される.

$$
\begin{aligned}
& \frac{d}{d \bar{r}}\left[\bar{r} \frac{d}{d \bar{r}}\left\{\frac{1}{\bar{r}} \frac{d}{d \bar{r}}\left(\bar{r} \bar{u}_{0}\right)\right\}\right] \\
& =\frac{1}{\bar{A}_{1} \bar{D}_{1}-\bar{B}_{1}^{2}}\left\{\bar{D}_{1} \frac{d}{d \bar{r}}\left(\bar{r} \frac{d \bar{N}^{T}}{d \bar{r}}\right)\right. \\
& \left.\quad-\bar{B}_{1} \frac{d}{d \bar{r}}\left(\bar{r} \frac{d \bar{M}^{T}}{d \bar{r}}\right)\right\} \ldots \ldots \ldots \ldots \ldots \\
& \frac{d}{d \bar{r}}\left[\bar{r} \frac{d}{d \bar{r}}\left\{\frac{1}{\bar{r}} \frac{d}{d \bar{r}}\left(\bar{r} \frac{d \bar{w}}{d \bar{r}}\right)\right\}\right] \\
& =\frac{1}{\bar{A}_{1} \bar{D}_{1}-\bar{B}_{1}^{2}}\left\{\bar{B}_{1} \frac{d}{d \bar{r}}\left(\bar{r} \frac{d \bar{N}^{T}}{d \bar{r}}\right)\right. \\
& \left.-\bar{A}_{1} \frac{d}{d \bar{r}}\left(\bar{r} \frac{d \bar{M}^{T}}{d \bar{r}^{T}}\right)\right\} \ldots \ldots \ldots \ldots \ldots . . . \cdots
\end{aligned}
$$

ただし， $\bar{N}^{T}, \bar{M}^{T}$ は熱合力，熱合モーメント $N^{T}, M^{T}$ の無次元值, $\overline{A_{1}}, \bar{B}_{1}, \bar{D}_{1}$ は円板の剛性成分 $A_{1}, B_{1}, D_{1}$ の無次元值を意味し，次式で表される。

$$
\begin{aligned}
& \left\{\begin{array}{l}
\bar{N}^{T} \\
\bar{M}^{T}
\end{array}\right\}=\sum_{i=1}^{N} \frac{\bar{E}_{i} \bar{\alpha}_{i}}{1-\nu_{i}} \int_{\overline{h_{i-1}}}^{\bar{h}_{i}} \bar{T}_{i}\left\{\begin{array}{c}
1 \\
\bar{z}
\end{array}\right\} d \bar{z} \\
& \left\{\begin{array}{l}
\overline{A_{1}} \\
\bar{B}_{1} \\
\bar{D}_{1}
\end{array}\right\}=\sum_{i=1}^{N} \frac{\overline{E_{i}}}{1-\nu_{i}^{2}}\left\{\begin{array}{c}
\overline{h_{i}}-\overline{h_{i-1}} \\
\frac{\bar{h}_{i}^{2}-\overline{h_{i-1}^{2}}}{2} \\
\frac{\bar{h}_{i}^{3}-\overline{h_{i-1}^{3}}}{3}
\end{array}\right\} .
\end{aligned}
$$

上式に扔いて， $\bar{h}_{i}$ は中央面から $i$ 番めの層の上面まで の距離 $h_{i}$ の)無次元表示を意味し，次式で与えられる.

$$
\bar{h}_{i}=\sum_{p=1}^{i} \bar{l}_{p}-\frac{\bar{H}}{2}
$$

平衡方程式(18)，(19)を逐次積分により解けば，円板 の熱変形および熱応力の解は以下のように求められ る.

$$
\begin{aligned}
\bar{u}_{0} & =\frac{1}{\bar{A}_{1} \bar{D}_{1}-\bar{B}_{1}^{2}}\left(\bar{D}_{1} \bar{N}^{T}-\bar{B}_{1} \bar{M}^{T}\right) \frac{\bar{r}}{2}+c_{2} \bar{r} \\
& \cdots \cdots \cdots \cdots(23) \\
\bar{w} & =\frac{1}{\bar{A}_{1} \bar{D}_{1}-\bar{B}_{1}^{2}}\left(\bar{B}_{1} \bar{N}^{T}-\bar{A}_{1} \bar{M}^{T}\right) \frac{\bar{r}^{2}}{4}+c_{1}^{\prime} \bar{r}^{2}+c_{2}^{\prime} \\
& \ldots \ldots \ldots \cdots(24) \\
\bar{\sigma}_{i}\left(=\bar{\sigma}_{r r i}=\bar{\sigma}_{\theta \theta i}\right) & \bar{E}_{i}\left[\frac { 1 } { 2 } \frac { 1 } { \overline { A } _ { 1 } \overline { D } _ { 1 } - \overline { B } _ { 1 } ^ { 2 } } \left\{\left(\bar{D}_{1} \bar{N}^{T}-\bar{B}_{1} \bar{M}^{T}\right)\right.\right. \\
& \left.\left.-\bar{z}\left(\bar{B}_{1} \bar{N}^{T}-\bar{A}_{1} \bar{M}^{T}\right)\right\}+c_{2}-2 \bar{z} c_{1}^{\prime}-\bar{\alpha}_{i} \bar{T}_{i}\right]
\end{aligned}
$$

ただし， $c_{2}, c_{1}^{\prime}, c_{2}^{\prime}$ は力学的境界条件から決定される末 定定数である。

ここで, 円板の端面で半径方向変位が自由な単純支 持条件を想定する， $\bar{N}, \bar{M}$ をそれぞれ，合力および合 モーメント $N, M$ の無次元值とすれば, 円板の力学的 境界条件は次式で表される。

$$
\bar{r}=1: \bar{N}=0, \bar{M}=0, \bar{w}=0 \cdots
$$

また， $\bar{N}, \bar{M}$ は次式で表される. 


$$
\left\{\begin{array}{c}
\bar{N} \\
\bar{M}
\end{array}\right\}=\sum_{i=1}^{N} \int_{\bar{h}_{t-1}}^{\bar{h}_{i}} \bar{\sigma}_{i}\left\{\begin{array}{l}
1 \\
\bar{z}
\end{array}\right\} d \bar{z}
$$

式 (23) 〜 (25), (27) を式(26)へ代入すれば, 未定定数 $c_{2}, c_{1}^{\prime}, c_{2}^{\prime}$ が求められる.

以上の熱曲げに関する解析，すなわち式(15)〜 (26) において導入された無次元量は次式で定義される.

$$
\begin{aligned}
& \left(\bar{r}, \bar{z}, \bar{h}_{i}, \bar{H}\right)=\left(r, z, h_{i}, H\right) / R \\
& \left(\bar{u}_{0}, \bar{w}\right)=\left(u_{0}, w\right) /\left(\alpha_{0} T_{0} R\right) \\
& \left(\bar{\varepsilon}_{r r i}, \bar{\varepsilon}_{\theta \theta i}\right)=\left(\varepsilon_{r r i}, \varepsilon_{\theta \theta i}\right) /\left(\alpha_{0} T_{0}\right) \\
& \left(\bar{\sigma}_{i}, \bar{\sigma}_{r r i}, \bar{\sigma}_{\theta \theta i}\right)=\left(\sigma_{i}, \sigma_{r r i}, \sigma_{\theta \theta i}\right) /\left(\alpha_{0} T_{0} E_{0}\right) \\
& \bar{E}_{i}=E_{i} / E_{0} \\
& \bar{\alpha}_{i}=\alpha_{i} / \alpha_{0} \\
& \bar{A}_{1}=A_{1} /\left(E_{0} R\right) \\
& \bar{B}_{1}=B_{1} /\left(E_{0} R^{2}\right) \\
& \bar{D}_{1}=D_{1} /\left(E_{0} R^{3}\right) \\
& \left(\bar{N}^{T}, \bar{N}\right)=\left(N^{T}, N\right) /\left(\alpha_{0} T_{0} E_{0} R\right) \\
& \left(\bar{M}^{T}, \bar{M}\right)=\left(M^{T}, M\right) /\left(\alpha_{0} T_{0} E_{0} R^{2}\right)
\end{aligned}
$$

ただし， $\alpha_{0}, E_{0}$ はそれぞれ基準となる線膨張係数およ び縦弾性係数である.

$2 \cdot 3$ 材料組成の最適化問題熱応力に対する強 度の確保と熱負荷に対する遮熱性の向上という二つの 目的を同時に達成する最適材料組成分布の決定を多目 的最適化問題として取扱う.

まず, 不均質体の材料組成を, 図 2 に示すように, 冷却側表面で金属, 加熱側表面でセラミックの組成を 持ち，かつ，体積組成分率が円板の板厚方向に関して 連続的に変化する次の関数として設定する.

$$
\begin{aligned}
& V_{m}=\left\{\begin{array}{l}
\left(\frac{1}{2}-\frac{z}{H}\right)^{1 / M}, 0<M \leq 1 \\
1-\left(\frac{z}{H}+\frac{1}{2}\right)^{M}, M \geq 1
\end{array}\right\} \\
& V_{c}=1-V_{m}
\end{aligned}
$$

ただし， $V_{m}, V_{c}$ はそれぞれ，金属打よびセラミックの 体積分率, $M$ は材料組成分布に関する傾斜パラメー

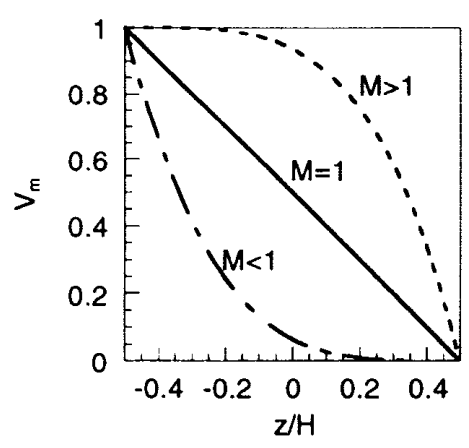

Fig. 2 Volume fraction
タである。

次に, 熱応力に対する強度を示す指標として, 次式 で表される応力比の絶対值の全時空間での最大値を採 用する。

$$
\begin{array}{r}
f_{\max }=\max \left(\left|\bar{\sigma}_{i} / \bar{\sigma}_{B i}\right|\right) \\
\left\{\begin{array}{l}
\bar{\sigma}_{B i}=\bar{\sigma}_{c i}, \bar{\sigma}_{i}<0 \\
\bar{\sigma}_{B i}=\bar{\sigma}_{t i}, \bar{\sigma}_{i} \geq 0
\end{array}\right\}
\end{array}
$$

ただし， $\sigma_{c i}, \sigma_{t i}$ はそれぞれ，各層の圧縮および引張り に対する強度を意味する。

一方，遮熱性の指標としては，次の二つの定常扔よ び非定常状態での熱流束を代表する各量をとりあげ る.

（1）円板を通過する熱流束の最大值

$$
\begin{aligned}
& \bar{q}_{t \max }=\bar{K}\left(\bar{T}_{b}-\bar{T}_{a}\right) \ldots \ldots \ldots \ldots \\
& \frac{1}{\bar{K}}=\frac{1}{H_{a} \bar{\lambda}_{1}}+\frac{1}{H_{b} \bar{\lambda}_{N}}+\sum_{i=1}^{N} \frac{\bar{l}_{i}}{\bar{\lambda}_{i}}
\end{aligned}
$$

ただし， $\bar{K}$ は熱通過率(5)(6) $K(1 / K$ : 熱抵抗)の無次元 表示を意味する。

（2）円板の加熱側表面から流入する熱流束の最大 値

$$
\begin{aligned}
\bar{q}_{i \max } & =\bar{\lambda}_{N}\left\{B_{N}^{\prime}+\sum_{j=1}^{\infty} \frac{2}{\mu_{j} \Delta^{\prime}\left(\mu_{j}\right)}\right. \\
\times & \left.\times\left(-\bar{A}_{N} \beta_{N j} \sin \beta_{N j} \bar{l}_{N}+\bar{B}_{N} \beta_{N j} \cos \beta_{N j} \bar{l}_{N}\right)\right\}
\end{aligned}
$$

そして, 材料組成最適化の目的関数として, 強度と遮 熱性を考慮した，次式で表されるスカラ関数 $F(M)$ を 導入する.

$$
\begin{aligned}
& F(M)=\frac{1}{\sqrt{w_{1}^{2}+w_{2}^{2}+w_{3}^{2}}} \\
& \times\left(w_{1} f_{\max }+w_{2} Q_{t \max }+w_{3} Q_{i \max }\right) \\
& \left.Q_{t \max }=\bar{q}_{t \max } / \bar{q}_{t 0}\right\} \\
& Q_{i \max }=\bar{q}_{i \max } / \bar{q}_{i 0}
\end{aligned}
$$

ただし， $Q_{t \text { max }}, Q_{i \max }$ は最大通過熱流束比および最大 流入熱流束比を意味する，また，それらの基準となる $\bar{q}_{t 0}, \bar{q}_{i 0}$ としては, 円板の半径に対する板厚の比 $\bar{H}$ が 等しく, かつ $H_{a}=H_{b}=\infty$ の条件下での金属均質体の 通過熱流束および流入熱流束の各最大值を採用寸る。

また, $w_{i}\left(0 \leq w_{i} \leq 1, i=1,2,3\right)$ は強度および遮熱性 の各評価指標にかける重み係数(゙)である。

式 (30) 〜 (35)で導入された無次元量は次式で定義さ れる。

$$
\begin{aligned}
& \left(\bar{\sigma}, \bar{\sigma}_{B i}\right)=\left(\sigma, \sigma_{B i}\right) /\left(\alpha_{0} T_{0} E_{0}\right) \\
& \left(\bar{q}_{t \max }, \bar{q}_{i \max }, \bar{q}_{t 0}, \bar{q}_{i 0}\right)=\left(q_{t \max }, q_{i \max }, q_{\imath 0}, q_{i 0}\right) \\
& \quad \times\left(\lambda_{0} T_{0}\right) / R \\
& \bar{K}=K \cdot R / \lambda_{0}
\end{aligned}
$$


式(34)で表される目的関数の最適化にあたり，式(32) で表される重み係数 $w_{i}(i=1,2,3)$ として, 任意の做 を与えて材料組成分布の関数 $V_{m}(z), V_{c}(z)$ に関する パラメータ $M$ を決定変数として最小化を行う。な抢, 最適化手法として，修正 Powell 法(8) を使用した。

\section{3. 数値計算例と考察}

2 章で述べた理論解析結果抢よび材料組成最適化手 法を用いて，片側表面から一様加熱を受ける傾斜機能 円板を対象として, 強度と遮熱性を考虑した材料組成 の多目的最適化の数值シミュレーションを行った。

本数优計算では，不均質体の一例として，チタン合 金 $(\mathrm{Ti} 6 \mathrm{Al} 4 \mathrm{~V})$ とジルコニアセラミック $\left(\mathrm{ZrO}_{2}\right)$ とか らなる傾斜機能材料をとりあげた，数值計算で用いた 各物性値を表 1 に示す。なお，不均質体の各物性伯は Kernerの混合則を用いて推定し，物性値の無次元化 の基準值 $\lambda_{0}, c_{0}, \rho_{0}, \alpha_{0}, E_{0}$ として，チタン合金の做を用 いた。

また，川板の加熱条件，基準となる温度変化，板厚 比，仮想的な層の数㧍よび各層の厚さに関する計算諸 元を次式の上うに与えた。

$$
\left.\begin{array}{l}
\Theta_{0}=300 \mathrm{~K} \\
\Theta_{a}=300 \mathrm{~K} \\
\Theta_{b}=800 \mathrm{~K} \\
H_{a}=\infty \\
H_{b}=\infty \\
T_{0}=500 \mathrm{~K} \\
\bar{I}=0.3 \\
N=20 \\
\bar{l}_{i}=\bar{H} / N, i=1, \cdots, N
\end{array}\right)
$$

そして、式(34)の月的関数に含まれる重み係数 $w_{i}(i=$ 1,2,3)については，次の二とおりにより変化する場合

\begin{tabular}{|c|c|c|c|}
\hline Properties & & Ti-6Al-4V & $\mathrm{ZrO}_{2}$ \\
\hline Thermal conductivity & {$[\mathrm{W} / \mathrm{mK} \mathrm{K}]$} & 6.2 & 1.7834 \\
\hline $\begin{array}{l}\text { Specific heat } \\
\text { Density }\end{array}$ & $\begin{array}{l}{[\mathrm{kJ} / \mathrm{kgK}]} \\
{\left[\mathrm{kg} / \mathrm{m}^{3}\right]}\end{array}$ & $\begin{array}{l}0.5377 \\
4.420 \times 10^{3}\end{array}$ & $\begin{array}{l}0.4614 \\
3.657 \times 10^{3}\end{array}$ \\
\hline $\begin{array}{l}\text { Coefficient of linear } \\
\text { thermal expansion }\end{array}$ & {$[1 / / K]$} & $8.8559 \times 10^{-8}$ & $8.7830 \times 10^{-6}$ \\
\hline Young's modulus & [GPa] & $1.0575 \times 10^{2}$ & $1.1638 \times 10^{2}$ \\
\hline Poisson ratio & & 0.2984 & 0.3333 \\
\hline Tensile strength & [MPa] & $0.9974 \times 10^{3}$ & $0.1456 \times 10^{3}$ \\
\hline Compressive strength & {$[\mathrm{MPa}]$} & $0.9974 \times 10^{3}$ & $0.3128 \times 10^{4}$ \\
\hline
\end{tabular}
考えた。

Case $1: w_{1}, w_{2} \geq 0, w_{3}=0$

（最大応力比と最大通過熱流束比を考虑した材料組成 最適化)

Case 2: $w_{1}, w_{3} \geq 0, w_{2}=0$

Table 1 Material properties
(最大応力比と最大流入熱流束比を考慮した材料組成 最適化)

\begin{tabular}{|c|c|c|c|c|c|c|c|}
\hline$w_{3} / w_{1}$ & $w_{1} / w_{3}$ & $M_{o p t}$ & $f_{\max }$ & $Q_{1 \max }$ & $Q_{i_{\text {max }}}$ & $1 / f_{\text {max }}$ & $1 / R$ \\
\hline 0.00 & & 2.0891 & 0.24898 & 0.64130 & 0.41061 & 4.0164 & 0.46780 \\
\hline 0.40 & & 2.0891 & 0.24898 & 0.641 .30 & 0.41061 & 4.0164 & 0.46780 \\
\hline 0.80 & & 2.0891 & 0.24898 & 0.64130 & 0.41061 & 4.0164 & 0.46780 \\
\hline \multirow[t]{34}{*}{1.00} & & 2.0891 & 0.24898 & 0.64130 & 0.41061 & 4.0164 & 0.46780 \\
\hline & 0.8333 & 2.0891 & 0.24898 & 0.64130 & 0.41061 & 4.0164 & 0.46780 \\
\hline & 0.6250 & 2.0891 & 0.24898 & 0.64130 & 0.41061 & 4.0164 & 0.46780 \\
\hline & 0.5000 & 2.0891 & 0.24898 & 0.64130 & 0.41061 & 4.0164 & 0.46780 \\
\hline & 0.4167 & $2.089 !$ & 0.24898 & 0.64130 & 0.41061 & 4.0164 & 0.46780 \\
\hline & 0.3571 & 2.0032 & 0.25501 & 0.63410 & 0.40834 & 3.9214 & 0.47312 \\
\hline & 0.3125 & 1.6967 & 0.28178 & 0.60577 & 0.39949 & 3.5489 & 0.49524 \\
\hline & 0.2778 & 1.1923 & 0.34507 & 0.54792 & 0.38105 & 2.8980 & 0.54753 \\
\hline & 0.2500 & 1.0000 & 0.37896 & 0.52091 & 0.37178 & 2.6388 & 0.57592 \\
\hline & 0.2273 & 1.0000 & 0.37896 & 0.52091 & 0.37178 & 2.6388 & 0.57592 \\
\hline & 0.2083 & 0.99167 & 0.38201 & 0.51943 & 0.37114 & 2.6177 & 0.57756 \\
\hline & 0.1923 & 0.95537 & 0.39593 & 0.51287 & 0.36836 & 2.5257 & 0.58495 \\
\hline & 0.1786 & 0.92249 & 0.40949 & 0.50681 & 0.36585 & 2.4421 & 0.59194 \\
\hline & 0.1667 & 0.89102 & 0.42337 & 0.50092 & 0.36346 & 2.3620 & $0.5989]$ \\
\hline & 0.1562 & 0.86164 & 0.43720 & 0.49532 & 0.36123 & 2.2873 & 0.60568 \\
\hline & 0.1471 & 0.83538 & 0.45032 & 0.49023 & 0.35924 & 2.2206 & 0.61196 \\
\hline & 0.1389 & 0.80961 & 0.46392 & 0.48518 & 0.35729 & 2.1555 & 0.61834 \\
\hline & 0.1316 & 0.78468 & 0.47779 & 0.48022 & 0.35542 & 2.0930 & 0.62473 \\
\hline & 0.1250 & 0.76177 & 0.49120 & 0.47560 & 0.35370 & 2.0358 & 0.63079 \\
\hline & 0.1190 & 0.73982 & 0.50464 & 0.47112 & 0.35206 & 1.9816 & 0.63679 \\
\hline & 0.1136 & 0.71812 & 0.51852 & 0.46664 & 0.35044 & 1.9286 & 0.64290 \\
\hline & 0.1087 & 0.69767 & 0.53215 & 0.46237 & 0.34893 & 1.8792 & 0.64884 \\
\hline & 0.1042 & 0.67726 & 0.54629 & 0.45806 & 0.34742 & 1.8305 & 0.65494 \\
\hline & 0.1000 & 0.65634 & 0.56133 & 0.45359 & 0.34589 & 1.7815 & 0.66139 \\
\hline & 0.09615 & 0.63583 & 0.57659 & 0.44917 & 0.34439 & 1.7343 & 0.66791 \\
\hline & 0.09259 & 0.61448 & 0.59302 & 0.44451 & 0.34284 & 1.6863 & 0.67491 \\
\hline & 0.08929 & 0.59034 & 0.61220 & 0.43918 & 0.34110 & 1.6335 & 0.68310 \\
\hline & 0.08621 & 0.55993 & 0.63714 & 0.43237 & 0.33891 & 1.5695 & 0.69386 \\
\hline & 0.08333 & 0.52798 & 0.66405 & 0.42510 & 0.33662 & 1.5059 & 0.70573 \\
\hline & 0.08065 & 0.52743 & 0.66453 & 0.42497 & 0.33658 & 1.5048 & 0.70594 \\
\hline & 0.07812 & 0.52740 & 0.66454 & 0.42497 & 0.33657 & 1.5048 & 0.70595 \\
\hline & 0.07576 & 0.52743 & 0.66452 & 0.42497 & 0.33658 & 1.5048 & 0.70594 \\
\hline & 0.07353 & 0.52741 & 0.66454 & 0.42497 & 0.33657 & 1.5048 & 0.70594 \\
\hline & 0.07143 & 0.50001 & 0.69308 & 0.41864 & 0.33460 & 1.4428 & 0.71662 \\
\hline
\end{tabular}

以下に上述の Case 1, Case 2 に対する数值計算結 果示す。

表 2(a)，(b)は，重み係数比，最適材料組成パラメ 一夕值 $M_{\mathrm{opt}}$, 最大応力比 $f_{\mathrm{max}}$, 最大通過熱流束比

Table 2 Results of optimization for each weights (a) Case 1

\begin{tabular}{|l|l|l|l|l|l|l|l|}
\hline$w_{z} / w_{1}$ & $w_{1} / w_{2}$ & $M_{\text {of }}$ & $f_{\max }$ & $Q_{\text {mmax }^{\prime}}$ & $Q_{i \max }$ & $1 / f_{\max }$ & $1 / R$ \\
\hline 0.0 & & 2.0891 & 0.24898 & 0.641 .30 & 0.41061 & 4.0164 & 0.46780 \\
0.2 & & 2.0891 & 0.24898 & 0.641 .30 & 0.41061 & 4.0164 & 0.46780 \\
0.4 & & 2.0891 & 0.24898 & 0.64130 & 0.41061 & 4.0164 & 0.46780 \\
0.6 & & 2.0891 & 0.24898 & 0.64130 & 0.41061 & 4.0164 & 0.46780 \\
0.8 & & 2.0891 & 0.24898 & 0.64130 & 0.41061 & 4.0164 & 0.46780 \\
1.0 & 1.0000 & 1.6842 & 0.28303 & 0.60452 & 0.39910 & 3.5332 & 0.49626 \\
& 0.83333 & 1.1917 & 0.34517 & 0.54784 & 0.38102 & 2.8971 & 0.54761 \\
& 0.71429 & 1.0000 & 0.37896 & 0.52091 & 0.37178 & 2.6388 & 0.57592 \\
& 0.62500 & 1.0000 & 0.37896 & 0.52091 & 0.37178 & 2.6388 & 0.57592 \\
& 0.55556 & 1.0000 & 0.37896 & 0.52091 & 0.37178 & 2.6388 & 0.57592 \\
& 0.50000 & 1.0000 & 0.37896 & 0.52091 & 0.37178 & 2.6388 & 0.57592 \\
& 0.45455 & 0.95005 & 0.39806 & 0.51190 & 0.36795 & 2.5122 & 0.58606 \\
& 0.41667 & 0.89442 & 0.42183 & 0.50156 & 0.36371 & 2.3706 & 0.59814 \\
& 0.38462 & 0.84372 & 0.44607 & 0.49186 & 0.35987 & 2.2418 & 0.60994 \\
& 0.35714 & 0.79642 & 0.47117 & 0.48256 & 0.35630 & 2.1224 & 0.62169 \\
& 0.33333 & 0.75110 & 0.49765 & 0.47343 & 0.35290 & 2.0094 & 0.63368 \\
& 0.31250 & 0.70614 & 0.52644 & 0.46414 & 0.34956 & 1.8996 & 0.64636 \\
& 0.29412 & 0.65889 & 0.55946 & 0.45414 & 0.34607 & 1.7874 & 0.66059 \\
& 0.27778 & 0.60169 & 0.60311 & 0.44169 & 0.34192 & 1.6581 & 0.67921 \\
& 0.26316 & 0.52741 & 0.66454 & 0.42497 & 0.33657 & 1.5048 & 0.70594 \\
& 0.25000 & 0.52741 & 0.66454 & 0.42497 & 0.33657 & 1.5048 & 0.70594 \\
& 0.23810 & 0.52741 & 0.66454 & 0.42497 & 0.33657 & 1.5048 & 0.70594 \\
& 0.22727 & 0.52741 & 0.66454 & 0.42497 & 0.33657 & 1.5048 & 0.70594 \\
& 0.21739 & 0.48927 & 0.70457 & 0.41613 & 0.33381 & 1.4193 & 0.72094 \\
\hline
\end{tabular}

(b) Case 2 


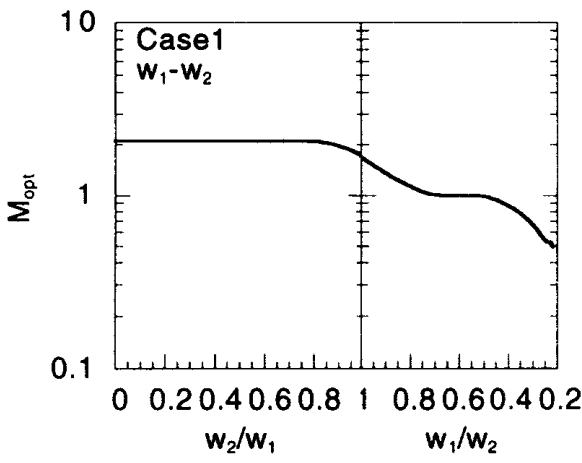

(a) Case 1

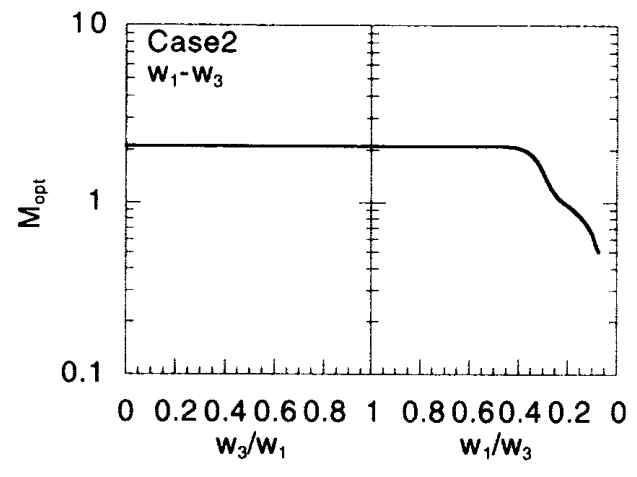

(b) Case 2

Fig. 3 Variations of optimal parameter $M_{\mathrm{opt}}$ with weight ratio

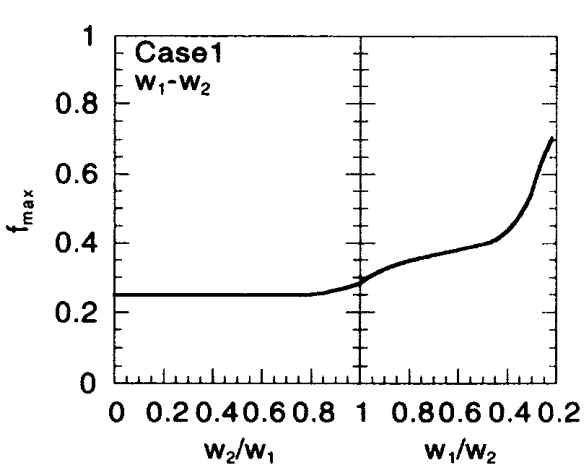

(a) Case 1

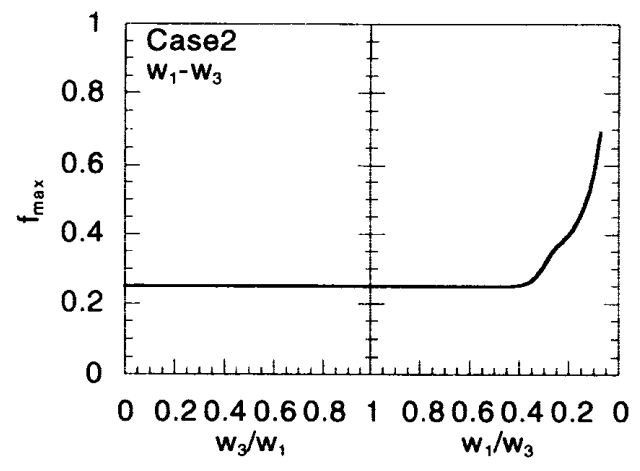

(b) Case 2

Fig. 4 Variations of maximum absolute stress ratio $f_{\max }$ with weight ratio

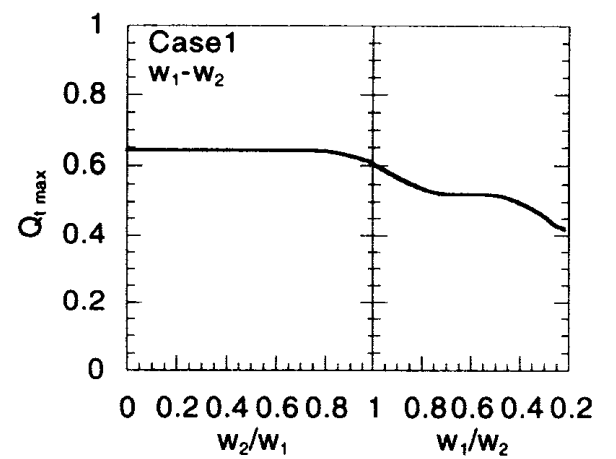

(a) Case 1

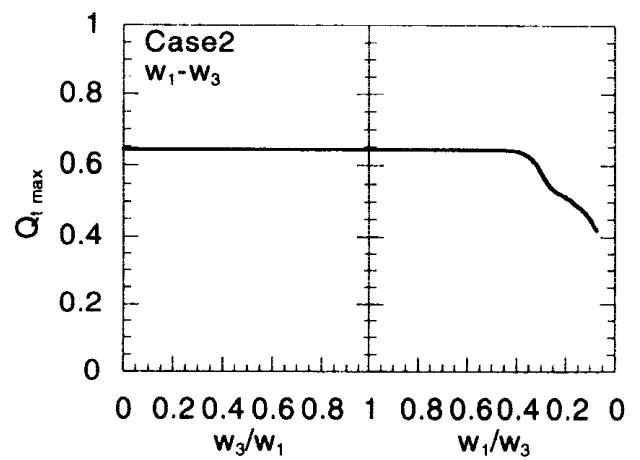

(b) Case 2

Fig. 5 Variations of maximum heat flux ratio of transmission $Q_{t \max }$ with weight ratio

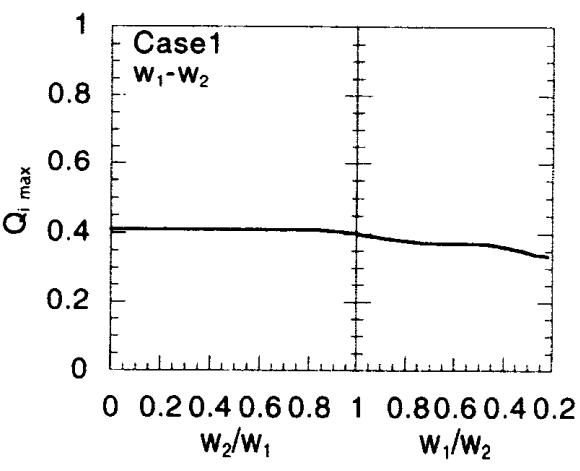

(a) Case 1

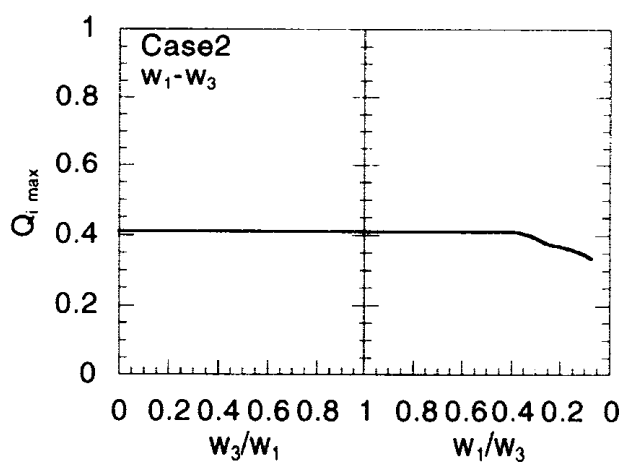

(b) Case 2

Fig. 6 Variations of maximum heat flux ratio of flow-in $Q_{t \max }$ with weight ratio 
$Q_{t \max }$, 最大流入熱流束比 $Q_{i \max }$, 最大応力比の逆数 $1 /$ $f_{\max }$ および無次元熱抵抗 $1 / \bar{K}$ の各值を示している. ここで, 最大応力比の逆数 $1 / f_{\max }$ は円板に生じる最大 応力を許容応力とした際の熱応力破壊に対する安全 率, また，無次元熱抵抗 $1 / \bar{K}$ は遮熱性の各指標を表す ものとみなすことができる。各表の第 2 行め $\left(w_{2} / w_{1}\right.$ $=0$ あるいは $\left.w_{3} / w_{1}=0\right)$ は, 最大応力比 $f_{\max }$ のみを考 慮した材料組成最適化の計算結果であり, 重み係数比 $w_{1} / w_{2}, w_{1} / w_{3}$ の値が小さくなるにつれ，最大通過熱 流束比あるいは最大流入熱流束比の考慮を重視した計 算結果に対応する。

図 3 は各ケースの最適材料組成パラメー夕值 $M_{\mathrm{opt}}$ の重み係数比による変化を示している. Case 1 では 重み係数比が $w_{2} / w_{1} \leq 0.8$, またCase 2 では $w_{1} / w_{3} \geq$ 0.4 の領域で, 最適材料組成パラメータ值 $M_{\mathrm{opt}}$ は 2.0891 となり, ジルコニアセラミックの体積分率 $V_{c}$ よりもチタン合金の体積分率 $V_{m}$ の多い材料組成分布 を示す。そして, 重み係数比 $w_{1} / w_{2}, w_{1} / w_{3}$ の減少と ともに，最適材料組成パラメー夕值 $M_{\mathrm{opt}}$ は低下し，材 料組成分布はジルコニアセラミックの体積分率の多い 分布へ変化することがわかる。

図 4 は各ケースの最大応力比 $f_{\max }$ の重み係数比に

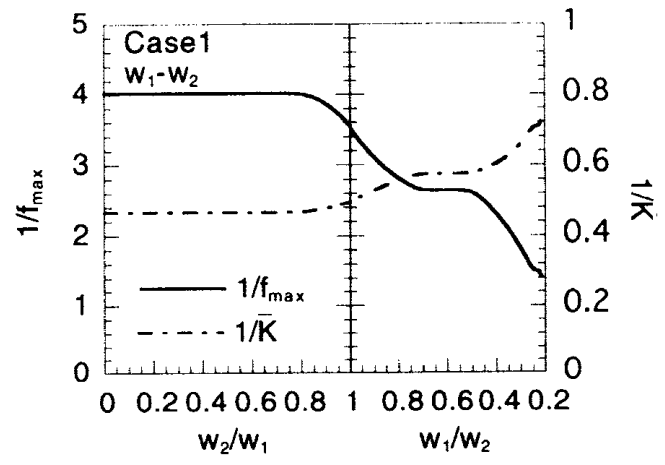

(a) Case 1

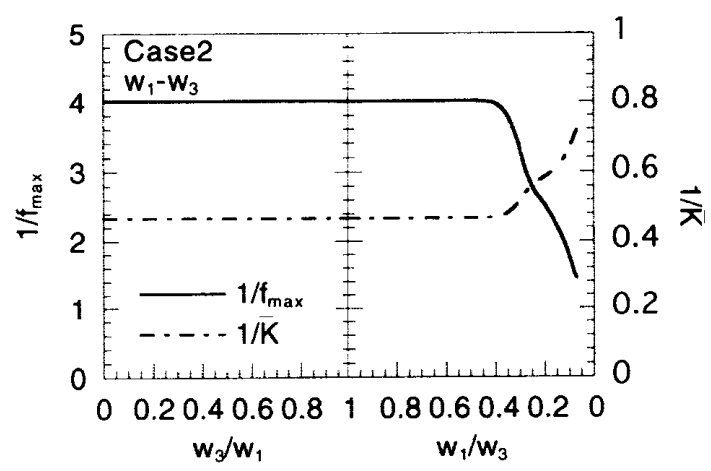

(b) Case 2

Fig. 7 Variations of inverse of absolute stress ratio 1/ $f_{\max }$ and normalized heat resistance $1 / R$ with weight ratio
よる変化を示している．両ケースとも重み係数比 $w_{1} /$ $w_{2}, w_{1} / w_{3}$ の滅少とともに, 最大応力比 $f_{\max }$ は増大す る.また, Case 1 では Case 2 に比べて, 重み係数比 の変化に対する最大応力比 $f_{\text {max }}$ の増大の割合は小さ い.

図 5,6 は各ケースの最大通過熱流束比 $Q_{t \max }$ およ び最大流入熱流束比 $Q_{i \max }$ の重み係数比による変化を 示している.両ケースとも重み係数比 $w_{1} / w_{2}, w_{1} / w_{3}$ の滅少とともに, 最大通過熱流束比 $Q_{t \max }$ および最大 流入熱流束比 $Q_{i \max }$ は減少する. 最大流入熱流束比 $Q_{i \max }$ は最大通過熱流束比 $Q_{t \max }$ よりも, 重み係数比 による值の変化は小さい.また, Case 2 では Case 1 に比べて, 重み係数比 $w_{1} / w_{2}, w_{1} / w_{3}$ の減少による最 大通過熱流束比 $Q_{t \max }$ および最大流入熱流束比 $Q_{i \max }$ の減少の割合は小さい.

図 7 は各ケースの最大応力比の逆数 $1 / f_{\max }$ および 無次元熱抵抗 $1 / \bar{K}$ の重み係数比による変化を示して いる. 重み係数比 $w_{1} / w_{2}, w_{1} / w_{3}$ の減少とともに, 最 大応力比の逆数 $1 / f_{\max }$ は減少する一方, 無次元熱抵抗 $1 / \bar{K}$ は増加し，両者の間にトレードオフの関係が見ら れる.すなわち, 重み係数比 $w_{1} / w_{2}, w_{1} / w_{3}$ を減少さ せることによって, 円板の遮熱性は向上するが，熱応 才破壊に対する強度の余裕度は低下寸ることがわか る.

図 8 はCase 1 について, 三とおりの重み係数比に 対する最大応力比 $f_{\text {max }}$, 最大通過熱流束比 $Q_{t \text { max }}$ お よ び最大流入熱流束比 $Q_{i \max }$ との関係を示したものであ る. 重み係数比が $w_{2} / w_{1}=0.0$ のとき, 最大応力比 $f_{\max }$ は他の重み係数比の場合に比べて最も小さいが, 最大通過熱流束比 $Q_{t \max }$ および最大流入熱流束比 $Q_{i \max }$ は大きく, 熱忘力に対する強度の確保を重視し た材料組成設計となる.また, 重み係数比 $w_{1} / w_{2}=$

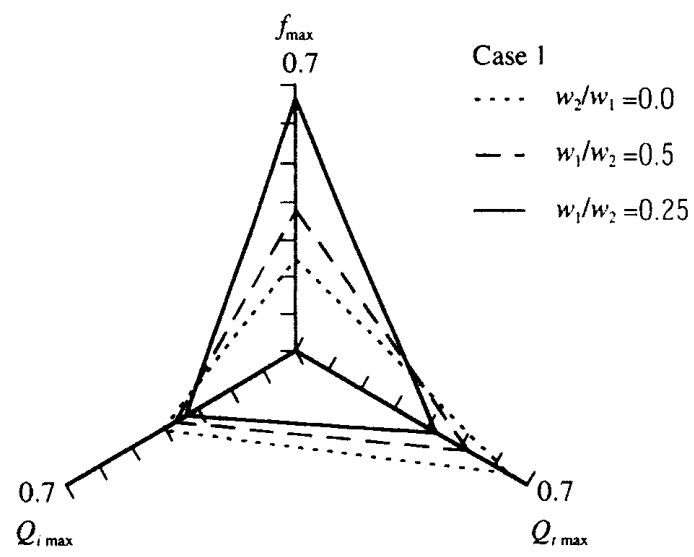

Fig. 8 Relationship of absolute stress ratio $f_{\max }$ and maximum heat flux ratios $Q_{t \max }$ and $Q_{i \max }$ 
$0.5,0.25$ では, $w_{2} / w_{1}=0.0$ の場合に比べて，熱角荷に 対する遮熱性の向上を重視した材料組成設計となる. したがって, 重み係数比の適切な選択によって, 最大 応力比 $f_{\max }$ の增大をある值までに抑え，かつ，最大通 過熱流束比 $Q_{t \max }$ を減少させることが可能であると考 えられる.すなわち，重み係数比の制御によって，熱 応力に対する強度と熱負荷に対する遮熱性の両特性を 考慮した材料組成の設計が可能であるといえる。

\section{4. 結言}

本研究では，表面一様加熱を受ける不均質円板の一 次元非定常熱伝導問題および熱曲げ問題を軸対称条件 のもとで理論解析した。次に，熱応力に対する強度と 熱負荷に対する遮熱性の向上という二つの目的を考虑 した不均質円板の材料組成の最適化問題を，多目的計 画法の一つである重み係数法に基づいて取扱った。そ して, 片側表面加熱を受けるチタン合金-ジルコニア セラミックス系傾斜機能円板を対象として, 熱応力に 対する強度の確保と熱負荷に対する遮熱性の向上とい う二つの目的を同時に達成するための材料組成の多目
的最適化の数值シミュレーションを実行した。数值シ ミュレーション結果から, 最大応力比と最大通過熱流 束比および最大流入熱流束比とのトレードオフ関係が 明らかにされた，さらに，熱応力に対する強度の確保 と熱負荷に対する遮熱性の向上を考慮した不均質材料 組成の多目的最適設計に対する本手法の有効性が示さ 机た。

\section{文献}

（1）傾斜機能材料研究会・社団法人未踏科学技術協会編，傾 斜機能材料, (1993)，3，工業謂榃会.

(2) Tanigawa, Y., Ootao, Y. and Kawamura, R., J. Ther. mal Stresses, 14-3 (1991), 285-308.

（3）谷川義倍 - 河村隆介, 機論, 57-540, A (1991), 1847-1853.

(4) Hetnarski. R. B. 編, Thermal Stress's I, (1986), 45, Elsevier.

（5）川崎完・日比野敦・渡辺龍三，H本金属学会誮， $\mathbf{5 6}$ $4(1992), 472-480$.

（6）熱力学教育研究会編，機械技術者のための熱力学，(1995)， 179 , 産業図書.

（7）坂和正:敏，非線形システムの最適化，(1986)，114，森北出 版.

（8）嘉納秀明，システムの最適理論と最適化，(1987），82，コ口 十社. 